\title{
Evaluation of the Integrated Disease Post Guidelines Program (Posbindu PTM) in Buludoang Community Health Center Working Area Jeneponto Regency
}

\author{
Ahmad Iskandar ${ }^{1 *}$, Alwy Arifin², Hasanuddin Ishak ${ }^{3}$, Sukri Palutturi ${ }^{2},{\text { Amran } \text { Razak }^{2} \text {, Syamsuar }}^{3}$ \\ ${ }^{1}$ Student of Master Program in Public Health, Hasanuddin University, Indonesia \\ ${ }^{2}$ Department of Health Administration and Policy, Faculty of Public Health, Hasanuddin University, Indonesia \\ ${ }^{3}$ Department of Environmental Health, Faculty of Public Health, Hasanuddin University, Indonesia
}

\begin{tabular}{ll}
\hline DOI: $10.36348 /$ sjnhc.2020.v03i07.003 & | Received: 01.07 .2020 | Accepted: $10.07 .2020 \mid$ Published: 16.07 .2020 \\
*Corresponding author: Ahmad Iskandar &
\end{tabular}

Abstract

The prevalence of PTM shows an increasing trend and is the number one cause of death in Indonesia. Through Posbindu a screening of residents aged $\geq 15$ years is carried out as a step to prevent and control PTM risk factors. The purpose of this research is to evaluate the Integrated Disease Development Post Program (Posbindu PTM) in the work area of Buludoang Public Health Center in Jeneponto Regency, the focus of this research is to use system theory by looking at the components of input, process, output, and feedback. This research is qualitative research with a descriptive-analytic approach, through in-depth interviews, observation and document review. The research subjects consisted of 12 informants, selected by purposive sampling technique. Data were analyzed including stages, reduction, presentation, and drawing conclusions, testing the validity of using triangulation of data sources. The results of the study, the number of cadres in each Posbindu between 2-5 people and has not been supported by SK (Certificate) so that it is inadequate, found the limitations of Posbindu (Integrated Development Post) KIT and inspection sticks, there are no KIE (Communication, Information, and Health Education) modules and media and does not involve the village government in Posbindu funding. Planning is done every year but is not problem-oriented, Posbindu is not yet supported by an organizational structure, the implementation of activities is still carried out by the PTM Puskesmas program holder and there are stages that are not carried out optimally, especially tables 2 and 5. Monitoring through monitoring is not routine and only focuses on Public health center. Service coverage is $6.9 \%$ and far from the SPM (Minimum Service Standards) target, and no coaching steps have been made to improve. Improvements are needed in the system dimension by involving the village government to maximize the implementation of Posbindu.

Keywords: Evaluation, posbindu, prevention, control, non-communicable diseases.

Copyright @ 2020: This is an open-access article distributed under the terms of the Creative Commons Attribution license which permits unrestricted use, distribution, and reproduction in any medium for non-commercial use (NonCommercial, or CC-BY-NC) provided the original author and source are credited.

\section{INTRODUCTION}

Non Communicable Diseases (NCD) a concern because it accounted for 41 million or around $71 \%$ of the total 57 million deaths in the world in 2016 [1]. Various efforts to reduce the increase in PTM incidents have been made by the government. From the regulatory aspect, it can be seen through PMK RI Number 43 of 2016 concerning SPM Health Sector [2].

A form of community participation, Posbindu PTM (Integrated Disease Development Post Program) activities are carried out as a form of promotive, preventive service. Where Posbindu PTM Activities are proven to be able to improve knowledge, introspective attitudes, and public health status [3, 4].
The number of Posbindu in Jeneponto in 2019, there were 104 Posbindu, with service coverage reaching 28.07\%. Of the 19 Puskesmas in Jeneponto District, Buludoang Puskesmas is the Puskesmas with the highest number of Posbindu, which is 8 Posbindu and service coverage reaches $(23.46 \%)$ according to the 2019 Health Office report.

Looking at the data presented above, the service coverage of Posbindu PTM is still far from the target of $100 \%$ of the population aged $\geq 15$ years getting PTM risk factor screening. The low service coverage is strongly influenced by internal organizational factors. For this reason, an evaluation of the program to increase coverage must be carried out to get an overview of program implementation. The 
system approach was chosen because this approach will provide a holistic picture of the things that need to be maintained, improved, and replaced. On this basis, researchers are interested in evaluating the Posbindu PTM Program at the Buludoang Health Center in Jeneponto Regency.

\section{METHODS}

\section{Location and Research Design}

This type of research is a qualitative research with a descriptive-analytic approach. This research was conducted at Posbindu in the working area of the Buludoang Community Health Center.

\section{Population and Sample}

There were 12 informants, selected using purposive sampling consisting of the head of the P2PTM section, the head of the puskesmas, the PTM (Non-Communicable Disease) program holder, the village head, and Posbindu cadres.

\section{Method of collecting data}

Primary data were obtained by conducting indepth interviews with informants using interview guidelines. Secondary data is obtained by gathering information from the documents, books, articles, and journals studied.

\section{Data analysis}

Data were analyzed starting with the process of data reduction, data presentation, continued with the validity test using source triangulation techniques, and ending with drawing conclusions.

\section{RESULTS \\ Input}

\section{a. Human Resources}

The number of cadres in each village is different, and not all are supported by SK. There are still many cadres who do not understand well the tasks that must be carried out when implementing Posbindu.

".....if the cadres are different every Posbindu, but in the Decree, there are 4 people. If the quality of cadres is lacking, most of us all work but there are some who understand because we have been trained ... " (Informant 4, PTM PKM program holder)

"...5 cadres, there is no Posbindu cadre SK (Letter of Statement), only Posyandu ...." (Informant 12, Posbindu Cadre)

Based on document review in 4 villages in the working area of the Buludoang Community Health Center, there is 1 village that has issued a Posbindu cadre decree.

\section{b. Budget}

The Posbindu budget for BOP (Health Operational Assistance) has been budgeted by the
Puskesmas but does not involve the village government. Likewise with cadre incentive payments.

"... there is no assistance from the village government, from all Puskesmas ... "(Informant 11, Posbindu Cadre)

"... if there is no incentive for cadres in Posbindu, because it is not in the RKPdes (Village Government Work Plan) and no information has been provided by the Puskesmas ..." (Informant 6, Village Secretary)

Based on document review, the Health Office in the DPA (Budget Implementation Document) received a 2019 Regional Budget (APBD) of Rp.180,597,859,000 and in 2020 Rp. 121,314,893,000. Of the total Health Service budget, the budget for the PTM (Non-communicable Disease) section in 2019 is Rp. 235,000,000, while in 2020 Rp. 271,921,189. The budget is used for prevention and control of PTM activities, and mental disorders. In the POA (Plan of Action) of the Buludoang Puskesmas, the allocation of BOK (Health Operational Assistance) funds for PTM activities in 2019 amounted to Rp. 41,900,000 and in 2020 Rp. 17,100,000.

\section{c. Means}

"... There is a Posbindu KIT from the Health Office, but I don't know how much it actually is because of the assets held, but only 1 is used and I use it if the sticks are from the Puskesmas and are limited ..." (Informant 4, Buludoang Program Holder)

Interview passages indicate if there are internal communication problems in the Puskesmas so that there is only 1 Posbindu (Integrated Development Post) KIT for 4 villages. The contribution of the village government is not maximized due to lack of coordination, this can be seen from informant information:

"... the Village Government's support has not been maximized, while the Village funds are ready in the Village, but when there are no details, what we want to buy, we should not spend it wrong ..." (Informant 6, Village Secretary)

The results of the observation were no different from the results of the interviews, where Posbindu did not yet have a special place, and was carried out in the homes of residents.

\section{d. Methods}

Procurement of KIE Media (Communication, Information, and Education) in the form of modules, as well as educational media for Posbindu PTM are not yet available in Posbindu, this is in line with interviews with informants: 
"... if there is a monitoring book in Posbindu, training time is given, if there are no modules, leaflet brochures, but we have never submitted a request ..." (Informant 10, Cadre of Posbindu Buludoang)

\section{PROCESS}

\section{a. Planning}

Based on the results of the interview, planning was made by the PTM/NCD (Non-Communicable Disease) Puskesmas program,

"... the plan depends on what is proposed by the Puskesmas (Community Health Center) PTM program holder, ..." (Informant 3, Head of Buludoang Puskesmas)

The program holder was chosen, because it was considered as the person who knew the most problems in the field, where based on the results of the interview there were still limited human resources in terms of quality and quantity, infrastructure, and methods.

The results of the document review, Puskesmas planning has been carried out and stated in the POA, but there are no planning documents from the village government for Posbindu support. This is because the village government does not know the support that must be given because Posbindu has not been specifically socialized.

\section{b. Organizing}

Based on the results of the interview there has been a division of roles between cadres and health workers, but there has not been cross-sectoral involvement.

"... if I divide the tasks sometimes I direct the mothers to go there, check my friend to help me measure," (Informant 9, Posbindu Cadre)

"... All the active cadres, community leaders, and the Village Government have not yet helped ..." (Informant 11, Posbindu Cadre)

However, the results of the document review show if there is no organizational structure related to Posbindu, both for cadres and cross-sectoral involvement.

\section{c. Implementation}

Based on the results of the interview, the description of the implementation is still carried out by the PTM/NCD Puskesmas program holder, the involvement of cadres at all 5 stages of the table.

"... we wait for the officers to bring the tools, and at the same time be measured, Kr. Keboji all because not given a register book so we just help measure the presence of people, ... "(Informant 9, Posbindu Cadre)
"... almost all of my activities are involved, there is no division of tables so all together is done ...." (Informant 4, Buludoang Program Holder)

In addition, based on the results of observations, in the implementation, there are still types of checks that are not carried out routinely, especially GDS examinations, this is due to the limited inspection sticks. In addition, stage 5 of the table has not been carried out optimally, it can be seen by not doing table 2 (interview) and table 5 (education) stages

\section{d. Supervision}

Based on the results of the research, the Health Office has carried out monitoring to the Puskesmas, while Posbindu is not routinely carried out and uses a sample system. In addition monitoring by the Puskesmas is only if there are problems in the field.

"... I often do, so all programs are evaluated and sent directly to the Puskesmas ..." (Informant 1, Head of P2PTM (Prevention and Control of Non-Communicable Diseases)).

However, according to the results of the interview, monitoring has never been carried out to Posbindu (Integrated Development Post) by Puskesmas (Community Health Centers).

"... There has never been a drop in Puskesmas people, if the changes are still just like that, don't know later in 2020 ..." (Informant 11, Posbindu Cadre)

\section{Output}

"... If the coverage is still low, it is very low, if the recording is in accordance with the format and is done every month, but I immediately recapitulate the new and old visits, so I am used to recap 50\%, ...." (Informant 4, Buludoang Program Holder)

Excerpts from the interview above indicate that the coverage of services at the Buludoang Community Health Center is still low. And there is no separation between new and old patients. The method used is to cut $50 \%$ of the recapitulated report. Based on the review of the monthly report documents in 2019 of $6.9 \%$, covering 3 types of examinations, namely BMI, abdominal circumference, and blood pressure.

\section{Feedback}

"... Since 2017 until now there has been no improvement, that's all I did 2 cadres up to now still like that, so the hope was separated implementation, because if at the same time Posbindu and Posyandu, the mothers just examined, the fathers did not ... "(Informant 9, Posbindu cadre) 
"... it is also limited by tools and Posbindu KIT is still like that, if there is no exemplary Posbindu cadre selection, there is also no forum for stories with cadres in other villages, if we hope that Posbindu can be active later ..." (Informant 10, Posbindu Cadre).

Based on interview excerpts, since 2017 until the time of the interview, there has been no change, both in terms of quantity of cadre quality, suggestions for supporting the implementation of activities. On the other hand, cadres hope that Posbindu can be more active so that there will be improvements in the implementation of Posindu, where the initial steps that can be taken by separating the implementation of Posyandu and Posbindu are so that the community served is also increased and not focused only on mothers. From informants 20 it was also obtained an explanation if the efforts of coaching to motivate cadres through the selection of exemplary cadres, exemplary posbindu, and the establishment of communication forums could not be done.

\section{DISCUSSION}

The ideal number of cadres in every Posbindu is 5 people, the results of the study, Posyandu cadres are also Posbindu cadres and there are differences in the number of cadres in each Posbindu between 2-5 people. These results are in line with research [5]. In addition, the availability of cadres is not fully supported by SK (Letter of Statement). Thus, even though cadres are involved in activities, if there is no formal legitimacy in the form of the decree, it can be said that in general there are no Posbindu cadres.

Other findings from the results of the study, the training has been carried out and from a total of 17 cadres, only 5 cadres have participated in the training. However, the implementation of the 1-day training made the cadres did not understand the whole material (theory and practice). The training itself is useful to improve the ability of cadres, especially in measuring Anthropometry and Blood Pressure [6].

There are other options in order to improve the quality without training, namely by providing modules / SOPs and/or KIE (Communication, Information, and Education) media to cadres. The results of the study, there are no modules / SOPs and KIE Media. Such conditions are not appropriate amidst the limited quality of cadres, because the Module / SOP can be a factor that facilitates cadres in measuring risk factors in Posbindu [7]. On the other hand, the availability of promotional media/KIE, can facilitate cadres in conducting education so that the ability of the community to prevent PTM/NCD risk factors can be increased [8].
The next input component is Posbindu support facilities. Consists of Posbindu KIT, inspection sticks/reagents, and adequate place of implementation. The results of the Posbindu research do not yet have a special place and are still being carried out at the homes of residents, or sub-deputies. The selection of places is done by considering strategic locations so that people can easily reach them on foot. The availability of GDS and cholesterol examination sticks, there are limitations so they cannot cover the target [9]. Whereas for Posbindu KIT, based on the results of the study there were only 1 Set of Posbindu KIT used for 4 villages. In general indicators of relevance are appropriate, particularly in the selection of places, while indicators of the availability of Posbindu KIT and sticks/reagents are inadequate.

The main obstacle is not the maximum availability of human resources, facilities, and methods is due to the lack of cross-sectoral support and limited funds. Based on the technical guidelines for the implementation of Posbindu PTM, the minimum amount of budget allocation for Posbindu is not specified, but funding is needed to make the program sustainable. Funding can be sourced from the BOK, the Village Government, non-government organizations, and from the private sector. The results of the study, the Health Office has allocated a PTM budget as outlined in the DPA (Budget Implementation Document) in 2019 of Rp. 235,000,000, while in 2020 it was Rp271,921,189. At the Puskesmas level, the PTM budget uses BOK (Health Operational Assistance) funds, which in 2020 were reduced by Rp. 24,000,000. because the PTM program has entered as a priority activity and is mandated in the Minimum Service Standards (SPM) and is the number one cause of death in Indonesia.

Related to cross-sectoral involvement, the village government does not provide BOP support and cadre incentives. The results of the study, the reason for not paying incentives is because it does not synchronize with the RKPdes (Village Government Work Plan) and the limited village budget. However, there is a budget for activities related to $\mathrm{MCH}$ (maternal and child health), as well as infectious diseases and stunting. This condition shows that there are problems with coordination so that the village government does not understand the support that must be given to Posbindu.

Overall, the components in the input are not in accordance with the technical instructions for implementing Posbindu. There are still limitations on the quantity and quality of cadres, infrastructure, methods, and financing. Particularly for cost constraints, the decrease in the amount of PTM budget allocation becomes inappropriate, because there is a significant effect of the amount of budget realization on increasing service coverage [10]. Therefore, innovation breakthroughs are needed to obtain budgetary sources 
other than the health sector and the Village Government. Can be done with the activity of the Puskesmas to make proposals for implementing Posbindu to the private sector, as well as from nongovernment organizations.

The planning stage is a very important stage to direct the implementation of program activities, as long as it is based on a strong database at the time of its preparation. Planning in this study is focused on preparing the Organizational Work Plan (RKO). The results of the study, the Puskesmas planning approach, were carried out by the person in charge of the PTM (Non-communicable Disease) program to formulate the activities to be carried out, the formulation of the activities themselves based on observations in the field or empirical experience in the previous year. At a glance, the model shows the flow of planning for the bottom-up approach. But it cannot be said to be so, because, besides consideration of needs and desires, bottom-up planning also focuses on solving problems. The problem of Posbindu in each village can be different, but planning in uniformity still occurs. This is because there is no situation analysis and problem identification, where the two stages are the initial process before preparing the organization's work plan. Thus, it can be said if the Puskesmas planning is more Top-Down because there are efforts to integrate PTM activities according to the Minimum Service Standards (SPM) mandate.

Then for planning at the village level, based on the results of the study, there is no Planning document included in the APBdes (village income and expenditure budget) for Posbindu activities. Thus, the availability indicator is not yet optimal. On the other hand, the involvement of the village government is very much needed in providing support, considering that posbindu is a UKBM (Community-Based Health Effort).

The next function is organizing and based on research results, there is no Posbindu (Integrated Development Post) organizational structure found in each village, but in the implementation, there is a division of roles between health workers and cadres. However, even though it has been involved in the implementation, Posbindu has not performed its organizing function properly, seen from the indicator of structure availability. This is consistent with Soekidjo's opinion which explains, the existence of an organizational structure is a visualization of the functioning of organizing in management[11]. The organizational structure shows that there is division of labor and how different functions or activities are coordinated $[12,13]$.

The next management function is implementation. Implementation, Posbindu PTM has been routinely carried out every month, held in the morning, and integrated with Posyandu. In terms of the effectiveness of the merger is not right, but seeing the limitations of human resources owned, including efficiency [14].

In general, the implementation is still dominated by the PTM Puskesmas program holder. Cadre involvement was only at table 1 (registration) and partly at table 3 (measurement). While in table 2 (interviews) have not been conducted, it can be seen from the absence of risk factor interview instruments and family PTM history at the time of observation. Then on table 4 (examination) examination of GDS (blood glucose levels measured at that time), cholesterol, IVA (Visual Acetate Inspection), and Indra's examination is not done routinely. Likewise at table 5 (education and not continuing). The recording and reporting stage is still online, whereas online reporting, which is a PTM surveillance instrument (SI PTM), has not yet been carried out. Because SI PTM is not working because of the lack of quality cadres and online reporting training has not been conducted.

The next stage in the management function is supervision. Supervision has an important role in management to test whether the implementation of work is orderly, orderly, directed and aimed at its objectives. The results of the study, routine monitoring is carried out by the Department of Health to the Puskesmas. While monitoring to Posbindu has never been done either from the Health Office or from the Puskesmas. Thus, internal control has been carried out, but no external supervision has been carried out. This condition is not yet appropriate because by monitoring various things will be obtained related to the level of achievement of objectives, unsuccessful actions, obstacles, challenges, and certain threats in managing the Program.

The output in Posbindu PTM uses a coverage indicator. The indicator is used to see the extent to which programs in one area can reach the community. The monthly health center report format refers to the technical guidelines for the implementation of Posbindu PTM, there are 11 types of tests namely (BMI (Body Mass Index), abdominal circumference, blood pressure, blood sugar, blood cholesterol, blood triglycerides, pulmonary testing, IVA, breast examination, alcohol levels breathing, and amphetamine levels).

The coverage of the Posbindu PTM program at the 2019 Buludoang Community Health Center reached $6.9 \%$. Consists of 3 types of examinations namely (BMI, abdominal circumference, and blood pressure). The highest number of risk factors by sex is hypertension, where 113 women, 28 men. Under these conditions based on the type of scope and type of inspection carried out is still far from the expected target. In addition, the scope of services and the number of PTM sufferers reported needs to be verified again, 
because there was a mistake in recording, ie there was no separation at the time of recapitulation between new and old visits. In this way, a double recording will occur, so that if 1 person regularly visits Posbindu every month, at the end of the year there will be as many as 12 people. For improvements to the output component especially for recording and reporting, in order to avoid mistakes in recording. PTM surveillance system online, must be activated, this is proven to provide a better picture of risk factor data as a result of research conducted at Surabaya City Health Office [15].

The development of Posbindu can be said to be not good. Said to be not good because there are no corrective steps to resolve obstacles in the input variables and processes. Coaching that is in the form of budgeting support, building partnerships, improving quality, and motivating cadres is still not optimal. this can be seen from a number of informant interviews describing, if from the beginning Posbindu was formed until now there were no significant changes. As such, relevance indicators are not met.

\section{CONCLUSION}

Based on the description above, there are still limitations to the input variables, the quality and quantity of cadres inadequate, limited infrastructure, there are no modules and media for IEC (Communication, Information, and Education) and financing does not involve the village government. While the description of the application of management functions has not been going well, planning is not oriented to solving problems, organizing is not supported by the presence of organizational structure, implementation is still dominated by the PTM (NonCommunicable Disease) program holders of the Puskesmas, and there are several stages of 5 tables that are not carried out, and monitoring through monitoring has not been done to Posbindu. This condition can then have implications for the low coverage of Posbindu PTM servants, especially with no coaching steps taken. For this reason, it is expected that the health department and Puskesmas will conduct socialization and advocacy to the village government, in an effort to encourage cross-sector involvement in the Posbindu PTM program. In addition, it is hoped that there will be efforts to resolve the limitations on the quality of human resources through training activities.

\section{REFERENCES}

1. WHO. (2016). World health statistics 2016: monitoring health for the SDGs sustainable development goals: World Health Organization.

2. Minister of Health Regulations. (2016). Peraturan Menteri Kesehatan Republik Indonesia Nomor: 43 Tahun 2016 tentang Standar Pelayanan Minimal Bidang Kesehatan. Kemenkes RI, Jakarta.

3. Purdiyani, F. (2016). Pemanfaatan Pos Pembinaan Terpadu Penyakit Tidak Menular (POSBINDU
PTM) Oleh Wanita Lansia Dalam Rangka Mencegah Penyakit Tidak Menular di Wilayah Kerja Puskesmas Cilongok 1. Jurnal Kesehatan Masyarakat (e-Journal), 4(1), 470-480.

4. Widagdo, W., Yulita, I., \& Nuraeni, A. (2017). The Relation Between Practical Knowledge And Attitudes Toward Control Of Risk Factors For Non-Communicable Diseases In The Posbindu PTM Village Pondok Labu South Jakarta. In Proceeding Manado Health Polytechnic 1st International Conference, 1(1); 241-247.

5. Nugraheni, W. P., \& Hartono, R. K. (2018). Strategi penguatan program posbindu penyakit tidak menular di kota Bogor. Jurnal Ilmu Kesehatan Masyarakat, 9(3), 198-206.

6. Lusiyana, N. (2020). Optimalisasi Peran Kader Posbindu Dalam Deteksi Hipertensi Di Posbindu Kedungpoh Tengah Wonosari Yogyakarta. Jurnal Education and Development, 8(2), 167-167.

7. Windiastuti, K., \& Gunawan, I. M. A. (2019). Pengaruh Penerapan Sop Pengukuran Tinggi Badan Terhadap Ketrampilan Kader Dalam Pengukuran Tinggi Badan Balita Di Desa Donomulyo. Poltekkes Kemenkes Yogyakarta.

8. Andarmoyo, S. (2019, June). Pemberian pendidikan kesehatan melalui media leaflet efektif dalam peningkatan pengetahuan perilaku pencegahan tuberkulosis paru di kabupaten ponorogo. In Seminar Nasional Pendidikan 2015 (pp. 600-605).

9. Febrianti, R. (2017). Implementasi pelaksanaan pos pembinaan terpadu penyakit tidak menular (posbindu ptm) di puskesmas pucang sewu kota Surabaya. Publika, 5(5).

10. Saleh, H., Ismail, N., \& Adamy, A. (2018). Hubungan Realisasi Anggaran Bantuan Operasional Kesehatan (BOK) dengan Cakupan Indikator Kesehatan Ibu di Aceh Periode 20132015. Jukema (Jurnal Kesehatan Masyarakat Aceh), 4(2), 339-348.

11. Soekidjo, N. (2007). Kesehatan masyarakat ilmu dan seni. Rineka Cipta, Jakarta.

12. Ho, C. L., Lai, G. C., \& Lee, J. P. (2011). Organizational structure. Corporate Governance and Reinsurance Demand in the US Property Causality Insurance Industry, Working Paper. Washington State University.

13. Guadalupe, M., Li, H., \& Wulf, J. (2014). Who lives in the $\mathrm{C}$-suite? Organizational structure and the division of labor in top management. Management Science, 60(4), 824-844.

14. Mahardika, K., \& Utami, S. (2019). Implementasi Program Pencegahan Penyakit Tidak Menular Di Puskesmas Cangkringan Kabupaten Sleman. Wacana Publik, 13(01).

15. Ali, I. H. (2019). Pengembangan Sistem Informasi Surveilans Faktor Risiko Penyakit Tidak Menular (PTM) Melalui Posbindu Di Dinas Kesehatan Kota Surabaya. Thesis, Universitas Airlangga. 